\title{
Alternative to formaldehyde in artificial diet for sugarcane borer and its effects on the parasitoid
}

Wellington Ivo Eduardo ${ }^{*}$,Renato Franco Oliveira de Moraes', Luiz Fernando Veloso Almeida', Josy Aparecida dos Santos², Rafael Ferreira dos Santos' ${ }^{1}$, Sergio Antonio De Bortoli ${ }^{1}$

'São Paulo State University, School of Agricultural and Veterinarian Sciences, Jaboticabal, SP, Brazil.

${ }^{2}$ São Martinho Industry, Pradópolis, SP, Brazil.

*Corresponding author, e-mail: wellington_ie@hotmail.com

\begin{abstract}
The formaldehyde used as anti-contaminant agent in artificial diets of insects can cause serious risks to human health. However, there are products with the same purpose, but with less toxicity to humans. In this sense, the aim of this study was to evaluate the biological parameters of Diatraea saccharalis (Fabricius, 1794) (Lepidoptera: Crambidae) fed on an artificial diet containing different anti-infective agents to replace the formaldehyde, as well as analyze the effects on its parasitoid Cotesia flavipes (Cameron, 1891) (Hymenoptera: Braconidae). The experiment was conducted under a completely randomized design, studying the anticontaminant agents: sodium benzoate, potassium sorbate, 2-phenylphenol, and formaldehyde (standard diet), with deionized water as control. The larvae of sugarcane borer were fed on diets with the cited agents, and were daily observed for: larval and pupal periods, larval and pupal viabilities, number of unviable larvae, longevity, pupae weight, sex ratio and the adults fecundity. To analyze the effects of the anti-contaminant agents on the C. flavipes parasitoid, 50 larvae of sugarcane borer were parasitized and daily observed until the parasitoid pupae formation, being evaluated: number of adults emerged per pupal mass, longevity and sex ratio. D. saccharalis larvae are positively influenced by replacing formaldehyde to 2-phenylphenol in their diet, not causing significant deleterious effects to C. flavipes.
\end{abstract}

Keywords: Diatraea saccharalis; Cotesia flavipes, mass rearing, anti-infective agents

\section{Introduction}

Formaldehyde is a chemical compound

widely used in industries and laboratories for different purposes (Fenech et al., 2016), such as its use as an anti-contaminant in the composition of artificial diets for insect rearing. Professionals and students which work in these insect rearing laboratories may be exposed to alarming levels of this product, which can lead to several human health problems such as poisoning, allergies, asthma, lung injury and cancer (Tang et al., 2009).

Many studies have shown a significant change in the frequency of lymphocytes in people exposed to formaldehyde, causing a mutagenic effect on lymphocyte circulation or in lymphatic tissue, and may also cause reactions in nasal and oral cells, even at low levels of exposure (Fenech et al., 2016). In addition, a Brazilian resolution (RDC 35, June $3^{\text {rd }}$, 2008) prohibits the use of formaldehyde in the formulations of sanitizing products due to its carcinogenic effect, according to the International Agency for Research on Cancer (IARC) (Anvisa, 2008).

Thus, it is of fundamental importance to replace this chemical with substances with the same function and efficiency, but less toxic to humans. There are other anti-contaminants with lower toxicity, such as the sodium benzoate $\left(\mathrm{LD}_{50}\right.$ for rats> $1940 \mathrm{mg}^{\mathrm{kg}}{ }^{-1}$ ) (Ma, 2009); potassium sorbate $\left(\mathrm{LD}_{50}\right.$ for rats of 3800 to $\left.4300 \mathrm{mg} \cdot \mathrm{kg}^{-1}\right)$ 
(Reckitt Benckiser, 2010); and 2-phenylphenol $\left(\mathrm{LD}_{50}\right.$ for rats of 3200 to $3500 \mathrm{mg} \cdot \mathrm{kg}^{-1}$ ) (Tayama et al., 1983), all with lower toxicity than formaldehyde $\left(L_{50}\right.$ for rats of 100 mg. $\mathrm{kg}^{-1}$ ) (Deng et al., 2014). However, the implications of these anti-pollutants on artificial diets for insect development are uncertain.

In order to test these products, an artificial diet for Diatraea saccharalis (Fabricius, 1794) (Lepidoptera: Crambidae) was chosen, for being considered the main sugarcane pest in Brazil (Portela et al., 2010; Dinardo-Miranda et al., 2011; Dinardo-Miranda et al., 2012; Ambrosano et al., 2015) and its chemical control is not an economically viable tactic (Beuzelin et al., 2009; Huang et al., 2006) or efficient (Freitas et al., 2007). Thus, the use of biological agents is the most common and efficient control for this pest in Latin American countries (Weir et al., 2007), mainly with the use of the Cotesia flavipes (Cameron, 1891) (Hymenoptera: Braconidae) (Souza et al., 2014) that are artificially reared in laboratories, having as food substrates $D$. saccharalis larvae grown in artificial diets with formaldehyde in their composition.

The objective of this study was to evaluate the implications of the substitution of formaldehyde by the anti-contaminants sodium benzoate, potassium sorbate and 2-phenylphenol in the artificial diet of D. saccharalis and the effects on the C. flavipes parasitoid.

\section{Material and Methods}

The experiment was conducted at the Laboratory of Biology and Insect rearing (LBIR) of the Department of Plant Protection of UNESP / FCAV, Brazil, in the period from March to July 2014, under controlled conditions of temperature $\left(27 \pm 1^{\circ} \mathrm{C}\right)$, relative humidity $(70 \pm 10 \%)$ and photoperiod (12 hours of light per day). The insects used in the experiments were obtained from the São Martinho biofactory, Pradópolis, State of São Paulo, Brazil, and the sugarcane borer fed on an artificial feeding diet up to the 3rd instar, and with re-feeding until the end of the larval period. These diets were made following the methodology proposed by King and Hartley, 1985 (Table 1).

The anti-contaminants used in the diets to replace formaldehyde were: potassium sorbate (3.7 g), 2-phenylphenol (1.8 g) and sodium benzoate (3.7 g), compared to a standard diet (formaldehyde - $10 \mathrm{ml}$ ) and deionized water as control. The feed diets were individually prepared by transferring $20 \mathrm{ml}$ of the still liquid diet into 40 $\mathrm{ml}$ test tubes for further solidification. Ten tubes were used per treatment.

After cooling and solidification of the diet, approximately 50 eggs of $D$. saccharalis were added per tube, which were closed with cotton. The emerged larvae were kept in the respective diet until reaching the third instar, when they were transferred to the re-feeding diet. The diets were packed in plastic trays for cooling and solidification and then cut into uniform cube pieces $(2 \mathrm{~cm} \times 2 \mathrm{~cm}$ ), which were packed in Petri dishes with six centimeters in diameter and two in height, totaling 20 replications for each diet (treatment).

In each Petri dish, five third instar larvae of $D$. saccharalis were released, being the larvae parasitized by $C$. flavipes in 10 dishes. For the other half of the Petri dishes, with larvae without parasitism, the biological development of the insect was monitored daily, evaluating: larval and pupal period; larval and pupal viability; number of undeveloped larvae; weight of pupae with 24 hours; sex ratio, calculated by the formula:

$$
R S=\frac{N F}{(N F+N M)}
$$

where RS = sex ratio; NF = number of females; NM = number of male; and longevity of adults. The pupae were individualized in $40 \mathrm{ml}$ volume test tubes, using clear plastic film as a lid, perforated with an entomological pin to improve internal aeration.

The larvae that remained alive for 30 days, and did not turn into pupae, were counted and considered as undeveloped larvae, since they were small in size and had little mobility. This procedure was carried out with the intention that these few larvae did not influence the larval period, if some of them would complete this phase of the life cycle.

The first five couples from larvae fed on each treatment, which emerged on the same day, were individualized in PVC cages $20 \mathrm{~cm}$ high by $10 \mathrm{~cm}$ in diameter, lined with sulphite paper, 
Table 1. Feeding and re-feeding diets used for Diatraea saccharalis breeding according to King and Hartley's methodology (1985).

\begin{tabular}{|c|c|c|c|}
\hline \multicolumn{2}{|c|}{ Tube Diet (Feeding) } & \multicolumn{2}{|c|}{ Tray Diet (Re-feeding) } \\
\hline Ingredients & Amount & Ingredients & Amount \\
\hline Sugar & $50 \mathrm{~g}$ & Sugar & $270 \mathrm{~g}$ \\
\hline Soy bran & $550 \mathrm{~g}$ & Soy bran & $400 \mathrm{~g}$ \\
\hline Wheat germ & $50 \mathrm{~g}$ & Wheat germ & $100 \mathrm{~g}$ \\
\hline Nipagin & $33 \mathrm{~g}$ & Nipagin & $25 \mathrm{~g}$ \\
\hline Ascorbic Acid & $10 \mathrm{~g}$ & Ascorbic Acid & $5 \mathrm{~g}$ \\
\hline Choline Chloride & $2 \mathrm{~g}$ & Choline Chloride & $2 \mathrm{~g}$ \\
\hline Formaldehyde & $10 \mathrm{ml}$ & Formaldehyde & $10 \mathrm{ml}$ \\
\hline Vitamin solution & $60 \mathrm{ml}$ & Vitamin solution & $30 \mathrm{ml}$ \\
\hline Caragenate & $87 \mathrm{~g}$ & Caragenate & $105 \mathrm{~g}$ \\
\hline Ampicillin & 750 mg & Ampicillin & $500 \mathrm{mg}$ \\
\hline Vita gold@ & $3 \mathrm{ml}$ & Vita gold@ & $2 \mathrm{ml}$ \\
\hline Flagy|® & 2 pills & Flagy $\mid \circledast$ & 1 pill \\
\hline Yeast & $205 \mathrm{~g}$ & Acetic acid & $40 \mathrm{ml}$ \\
\hline Wesson's salts & $22 \mathrm{~g}$ & Water & $4000 \mathrm{ml}$ \\
\hline Water & $4000 \mathrm{ml}$ & & \\
\hline
\end{tabular}

and sealed with acrylic plates at the ends. Inside the cage was placed a cotton wad soaked in $10 \%$ honey solution, which was filled into a Petri dish of six centimeters in diameter. For this test, each cage represented a replication. The remaining adults were kept in the respective test tubes without food, to observe the longevity. The cages were inspected daily, and the eggs were removed and counted using a stereoscopic microscope $\left(40^{x}\right)$, determining: number of laying; number of eggs per laying and number of viable eggs.

The other half of the dishes, containing the larvae parasitized by C. flavipes, were observed daily until the parasitoid larvae were transformed into pupae (pupal mass formation). Ten pupae masses were randomly selected from each treatment (each mass was considered a replication), to determine the number of adults emerged by pupal mass. These adults were sexed for sex ratio calculation, using the formula cited previously for $D$. saccharalis. To determine the longevity of $C$. flavipes without food, the first 10 males and females emerged (each insect was considered a replication) were individualized in $1.5 \mathrm{ml}$ Eppendorf tubes. For this test, the mortality was assessed on every 12 hours.

The experiments were conducted in a completely randomized design, using 10 replications for the biological parameters of $D$. saccharalis, each composed of five insects. In the fecundity tests of $D$. saccharalis, five replications were used. For the number of adults emerged by mass of pupae and longevity of C. flavipes, 10 replications were used.

The data were submitted to the Levene test $(a=0.05)$ to observe the homoscedasticity of the variances and the "studentized" residues of each variable were submitted to the normal test of Cramer Von Mises ( $a=0.05$ ). It was also performed residue analyzes to identify outliers or influences; without observation of these assumptions, the data were transformed according to the Box-Cox test and submitted to analysis of variance by ANOVA. When significant $(p<0.05)$, the averages were compared by the Tukey's test $(a=0.05)$. All statistical tests were performed using the SAS 9.3 software.

The parameters that did not satisfy the homogeneity assumptions of the variances and / or normality of the residues, were submitted to the Kruskal-Wallis test and, when significant ( $p<0.05$ ), the means were compared by the Dunns's test $(a=0,05)$ using the GraphPad Prism 4 software.

\section{Results and Discussion}

The anti-contaminants, in the different treatments, significantly influenced the $D$. saccharalis larval and pupal viability. Insects fed on the control had lower larval viability compared to insects fed with diets containing sodium benzoate, formaldehyde and 2-phenylphenol, and lower pupal viability compared to insects fed with diets with sodium benzoate, formaldehyde, 
potassium sorbate and 2-phenylphenol (Table 2). Ramalho et al. (2012) affirmed that one of the main characteristics for an artificial diet to be considered as ideal is the providing of high viability of larvae and pupae, which was observed in this study for sodium benzoate, formaldehyde and 2-phenylphenol.

The percentage of undeveloped larvae was significantly higher when the insects were fed with the control diet, when compared to larvae in diets containing sodium benzoate, formaldehyde and phenylphenol (Table 2). The observed statistical differences were similar to those reported for larval viability. Thus, it is evident that the use of certain anti-contaminants in the D. saccharalis diet increases larval viability, providing a better development for the insect at this stage of its biological cycle.

The sugarcane borer diet in the different treatments did not affected the males and females proportion, with the sex ratio close to 0.5 (Table 2). The ratio between males and females is one of the parameters used to standardize the quality of the diets, so that the ratio of sex to less 0.5 (lower number of females than males), is usually a negative indicative for the quality standard of D. saccharalis (Vacari et al., 2012a).

Regarding the larval period, larvae fed in the control took longer to complete this phase of development, differing significantly from those fed diets containing sodium benzoate, potassium sorbate and 2-phenylphenol (Table 3).

Thus, it can be inferred that this cycle

Table 2. Means and standard error for the larval and pupal viability, percentage of undeveloped larvae and the sex ratio of Diatraea saccharalis fed on artificial diet containing different anti-contaminants.

\begin{tabular}{ccccc}
\hline \multirow{2}{*}{$\begin{array}{c}\text { Treatments } \\
\text { (diets) }\end{array}$} & \multicolumn{2}{c}{ Viability (\%) } & $\begin{array}{c}\text { Undeveloped larvae } \\
(\%)\end{array}$ & Sex ratio \\
\cline { 2 - 3 } & Larval & Pupal & $36.0 \pm 7.18 \mathrm{~b}$ & $0.6 \pm 0.13$ \\
Control & $32.0 \pm 9.98 \mathrm{a}$ & $30.6 \pm 10.01 \mathrm{a}$ & $2.0 \pm 2.00 \mathrm{a}$ & $0.6 \pm 0.09$ \\
Sodium benzoate & $98.0 \pm 2.00 \mathrm{~b}$ & $84.0 \pm 6.55 \mathrm{~b}$ & $4.0 \pm 4.00 \mathrm{a}$ & $0.4 \pm 0.09$ \\
Formaldehyde & $80.0 \pm 10.33 \mathrm{~b}$ & $81.5 \pm 6.16 \mathrm{~b}$ & $16.0 \pm 7.18 \mathrm{ab}$ & $0.6 \pm 0.10$ \\
Potassium sorbate & $72.0 \pm 12.00 \mathrm{ab}$ & $90.7 \pm 6.28 \mathrm{~b}$ & $0.0 \pm 0.00 \mathrm{a}$ & $0.6 \pm 0.05$ \\
2-phenylphenol & $100.0 \pm 0.00 \mathrm{~b}$ & $96.0 \pm 2.67 \mathrm{~b}$ & $25.03^{* *}$ & $4.57^{\mathrm{ns}}$ \\
\hline$H$ (diets) & $27.23^{* *}$ & $19.33^{* *}$ & 46 & 48.92 \\
CV & 34.84 & 22.80 &
\end{tabular}

Table 3. Means and standard error for the larval and pupal periods, adults longevity and pupae weight of Diatraea saccharalis fed with artificial diet containing different anti-contaminants.

\begin{tabular}{ccccc}
\hline \multirow{2}{*}{$\begin{array}{c}\text { Treatments } \\
\text { (diets) }\end{array}$} & Larval & Pupal & Longevity & Pupae weight (mg) \\
\cline { 2 - 4 } Control & $36.9 \pm 1.83 \mathrm{~b}$ & $8.4 \pm 0.24$ & $6.1 \pm 0.43$ & $181.9 \pm 17.3 \mathrm{ab}$ \\
Sodium benzoate & $29.3 \pm 0.45 \mathrm{a}$ & $8.1 \pm 0.19$ & $5.8 \pm 0.21$ & $184.6 \pm 8.55 \mathrm{~b}$ \\
Formaldehyde & $33.6 \pm 2.24 \mathrm{ab}$ & $8.1 \pm 0.17$ & $5.9 \pm 0.72$ & $147.7 \pm 8.17 \mathrm{a}$ \\
Potassium sorbate & $29.9 \pm 1.06 \mathrm{a}$ & $8.1 \pm 0.40$ & $4.8 \pm 0.28$ & $165.2 \pm 8.54 \mathrm{ab}$ \\
2-phenylphenol & $30.4 \pm 0.42 \mathrm{a}$ & $8.5 \pm 0.09$ & $6.0 \pm 0.22$ & $191.8 \pm 6.43 \mathrm{~b}$ \\
\hline $\mathbf{F}$ (diets) & $5.74^{* *}$ & $0.84^{\text {ns }}$ & $2.07^{\text {ns }}$ & $3.95^{* *}$ \\
CV & 30.89 & 3.92 & 11.18 & 7.9 \\
\hline $\begin{array}{l}\text { Means followed by different letters in the column are significantly different according to Tukey's test (P<0.05). nsNot significant by ANOVA (P<0.05). } \\
* * \text { Significant by ANOVA (P<0.01) }\end{array}$
\end{tabular}

elongation is probably due to contamination problems, that although not quantified, was observed visually signs of microorganisms development in control, whereas it was not verified when the anti-contaminants treatments were evaluated. Contaminants usually harm the insect development, especially as they significantly alter the quality of the artificial diet, reflecting in poor biological parameters.

The larval period is an important aspect to consider, since it is known that the shortest time for the insect to complete a certain phase of its life 
cycle promotes a greater number of generations over time, an aspect favorable to the population growth and, consequently, to promote higher effectiveness of mass production. Considering that the main objective of the mass production of $D$. saccharalis is to produce larvae to serve as food for the C. flavipes parasitoid, which in this case occurs generally when the larvae reach the third instar, the reduction of the time for the larvae to reach this stage would directly increase the efficiency of $C$. flavipes rearing, since it would decrease the time for parasitism, promoting a greater number of generations of host and parasitoid.

The anti-contaminants used in the diets did not significantly affected the pupal period and the longevity of the adults of the sugarcane borer (Table 3), which shows no influence of the anti-contaminants in these biological parameters. A shorter pupal period could be interesting when the objective is to optimize the rearing, by the same fact commented for the larval period, that is, the shorter the development phase, the greater the number of generations over time, which would increase the rearing efficiency. Longevity is not a very important parameter for insect mass production, since the main function of adults is reproduction, with oviposition being more significant at this stage of development
(Santos et al., 2015).

Pupae from larvae fed with sodium benzoate and 2-phenylphenol were heavier than those fed with formaldehyde (Table 3), which could be explained by a possible phagostimulant action of these anti-contaminants, which would provide a higher dietary intake by the larvae in the feeding process and as a consequence an increase in the pupae weight, or even, these products could, due to their specific action, have protected the diet from the qualitative degradation, which may have favored the ingestion, conversion and use of the food by the insect, leading to the production of better quality insects. This fact is in accordance with Vacari et al. (2012a), who affirmed that insect weight gain is an important development for large-scale production.

The fecundity of $D$. saccharalis adults was not influenced by diet during the immature phase for the different treatments, and there was no significant difference for the number of eggs. However, the viability of eggs from insect fed with sodium benzoate was significantly higher when compared with potassium sorbate (Table 4). Vacari et al. (2012b) point out that the quality and amount of food consumed by the larvae may affect adult fecundity and egg viability.

In the evaluation of the influence of

Tabela 4. Means and standard errors for the number of eggs, viability (\%), number of egg laying and number of eggs per laying of Diatraea saccharalis fed with an artificial diet containing different anti-contaminants.

\begin{tabular}{|c|c|c|c|c|}
\hline $\begin{array}{l}\text { Treatments } \\
\text { (diets) }\end{array}$ & Number of eggs & Viability (\%) & $\begin{array}{c}\text { Number of egg } \\
\text { layings }\end{array}$ & Eggs per laying \\
\hline Sodium benzoate & $519.6 \pm 70.46$ & $75.8 \pm 6.18 a$ & $8.8 \pm 1.28$ & $59.9 \pm 2.96$ \\
\hline Formaldehyde & $529.2 \pm 147.13$ & $69.9 \pm 7.34 \mathrm{ab}$ & $10.2 \pm 1.49$ & $48.9 \pm 5.80$ \\
\hline Potassium sorbate & $536.2 \pm 62.13$ & $46.6 \pm 8.74 b$ & $8.2 \pm 1.24$ & $66.6 \pm 3.62$ \\
\hline 2-phenylphenol & $535.6 \pm 129.31$ & $71.7 \pm 4.10 \mathrm{ab}$ & $7.8 \pm 1.11$ & $65.9 \pm 6.10$ \\
\hline $\mathrm{F}$ (diets) & $0.07^{n s}$ & $3.75^{*}$ & $0.72^{\text {ns }}$ & $2.89^{n s}$ \\
\hline C.V. & 6.41 & 23.05 & 14.51 & 17.85 \\
\hline
\end{tabular}

these anti-contaminants used in the diets of the sugarcane borer on C. flavipes parasitoids, it was observed that the number of adults of C. flavipes that emerged from the pupae masses was significantly higher when the larvae developed in D. saccharalis was submitted to potassium sorbate diet, when compared to diets with sodium benzoate, formaldehyde and control (Table 5). Greater viability in the breeding of large-scale natural enemies is directly related to the number of parasitoids that emerge from a pupal mass, since, according to Parra et al. (2002), the vigor of the pupae masses is one of the quality parameters that should be introduced in the protocols of $C$. flavipes breeding.

The sex ratio of $C$. flavipes was higher when parasitism occurred in $D$. saccharalis larvae developed with a diet containing formaldehyde, 
differing significantly when parasitized larvae were fed using the control, sodium benzoate and phenylphenol treatments (Table 5). The highest number of males than females (lower sex ratio) can be considered detrimental to the $C$. flavipes mass production, since the females are responsible for parasitism (Vacari et al., 2012a). Thus, according to Campos-Farinha et al. (2000), the ideal ratio between males and females for an effective control is $1: 1$, which was obtained only in formaldehyde and potassium sorbate diets.

The most long-lived parasitoids were those that parasitized D. saccharalis larvae fed with diet containing 2-phenylphenol and formaldehyde, differing from those that parasitized larvae fed with a diet containing sodium benzoate (Table 6). Analyzing males and females separately, it was observed that the most long-lived males were those that parasitized larvae fed with 2-phenylphenol, differing from those that developed in control, sodium benzoate and potassium sorbate diets. The females of $C$. flavipes that parasitized the larvae fed with formaldehyde and phenylphenol diets were significantly long-lived than those that parasitized the larvae fed with the diet containing sodium benzoate (Table 6). The higher longevity of the parasitoids represents an insect of better quality and with greater search capacity for prey under field conditions (Santos et al., 2015).

Table 5. Means and standard error for the number of emerged adults by pupae mass and sex ratio of Cotesia flavipes that parasitized Diatraea saccharalis larvae fed on artificial diet containing different anti-contaminants.

\begin{tabular}{ccc}
\hline Treataments (diets) & Number of emerged adults by pupae mass & Sex ratio $^{2}$ \\
\hline Control & $49.2 \pm 4.61 \mathrm{ab}$ & $0.3 \pm 0.03 \mathrm{a}$ \\
Sodium benzoate & $43.2 \pm 4.13 \mathrm{a}$ & $0.3 \pm 0.07 \mathrm{a}$ \\
Formaldehyde & $44.2 \pm 2.92 \mathrm{a}$ & $0.6 \pm 0.05 \mathrm{~b}$ \\
Potassium sorbate & $72.8 \pm 4.86 \mathrm{c}$ & $0.4 \pm 0.02 \mathrm{ab}$ \\
2-phenylphenol & $65.0 \pm 5.10 \mathrm{bc}$ & $0.3 \pm 0.02 \mathrm{a}$ \\
\hline F (diets) & $8.49^{* *}$ & - \\
H (diets) & - & $17.04^{* *}$ \\
C.V. & 6.56 & 35.26 \\
\hline
\end{tabular}

政 are different according to Dunns's test $(P<0.05)$. ${ }^{*}$ Significant by ANOVA or Kruskal-Wallis $(P<0.01)$.

Table 6. Means and standard error for the longevity of Cotesia flavipes that parasitized Diatraea saccharalis larvae fed on artificial diet containing different anti-contaminants.

\begin{tabular}{cccc}
\hline Treataments & \multicolumn{3}{c}{ Longevity (hours) } \\
\cline { 2 - 4 } (dietas) & Male and Female & Male & Female \\
\hline Control & $67.2 \pm 3.07 \mathrm{ab}$ & $63.6 \pm 2.56 \mathrm{ab}$ & $70.8 \pm 4.89 \mathrm{ab}$ \\
Sodium benzoate & $47.4 \pm 2.60 \mathrm{a}$ & $48.0 \pm 3.10 \mathrm{a}$ & $46.8 \pm 3.32 \mathrm{a}$ \\
Formaldehyde & $81.0 \pm 2.57 \mathrm{~b}$ & $72.0 \pm 2.53 \mathrm{bc}$ & $90.0 \pm 4.47 \mathrm{~b}$ \\
Potassium sorbate & $67.8 \pm 4.90 \mathrm{ab}$ & $66.0 \pm 4.82 \mathrm{ab}$ & $69.6 \pm 6.65 \mathrm{ab}$ \\
2-phenylphenol & $82.8 \pm 3.07 \mathrm{~b}$ & $88.8 \pm 3.67 \mathrm{c}$ & $76.8 \pm 4.80 \mathrm{~b}$ \\
\hline$H$ (diets) & $28.82^{* *}$ & $29.49^{* *}$ & $23.98^{* *}$ \\
C.V. & 15.32 & 16.08 & 22.07 \\
\hline Means followed by different letters in the column are different according to Dunns's test (P<0.05).
\end{tabular}

"Significant according to Kruskal-Wallis's test $(P<0.01)$.

It is also important to highlight that $D$. saccharalis larvae fed with a diet containing 2-phenylphenol presented high larval and pupal viability, low percentages of undeveloped larvae, short larval period and high pupal weight. When the parasitoids parasitized the larvae fed on the diet containing phenylphenol, a large number of parasitoids emerged by pupae mass, with large periods of longevity. In general, 2-phenylphenol has a great potential to replace formaldehyde in artificial diets for D. saccharalis, since formaldehyde is dangerous product to human health and it is toxic to various organisms (Tang et al., 2009). The 2-phenylphenol, besides having a much lower acute toxicity, still influencing positively the D. saccharalis and C. flavipes rearing. However, further studies with this anticontaminant are needed to better evaluate the risks to human health when used in insect rearing laboratories, as well as studies with different doses 
of the product to optimize the D. saccharalis rearing for the mass production of the natural enemy C. flavipes, besides economic viability studies for the use of this anti-contaminant in the substitution of formaldehyde.

\section{Conclusion}

D. saccharalis borers are positively influenced by the replacement of formaldehyde for 2-phenylphenol in its diet, with no harmful effects for C. flavipes.

\section{Acknowledgments}

São Martinho biofactory for the supply of insects and ingredients used in the preparation of diets.

\section{References}

Ambrosano, E.J., Lourenção, A.L., Wutke, E.B., Rossi, F., Dias, F.L.F., Tavares, S., Ambrosano, G.M.B. 2015. Infestation of Diatraea saccharalis (Fabr.) during five consecutive cycles of sugarcane crop succeeding leguminous crops. Agricultural Sciences, 6: 14-21.

Anvisa, 2008. http://www.anvisa.gov.br/divulga/ noticias/2008/rdc\%2035.pdf. <Accessed Abril 28th, 2016>.

Beuzelin, J.M., Reagan, T.E., Akbar, W., Cormier, H.J., Flanagan J.W., Blovin, D.C. 2009. Impact of hurricane rita storm surge on sugarcane borer (Lepidoptera: Crambidae) management in Lovisiana. Journal of Economic Entomology, 102: 1054-1061.

Campos-Farinha, A.E.C., Chd-Netto, J., Gobbi, N. 2000. Biologia reprodutiva de Cotesia flavipes (Cameauron) (Hymenoptera: Braconidae). Discriminação entre lagartas parasitadas e não parasitadas de Diatraea saccharalis Fabricius (Lepidoptera: Pyralidae), tempo de desenvolvimento e razão sexual dos parasitoides. Arquivos do Instituto Biológico 67: 229-234.

Deng, S., Pizzi, A., Du, G. Zhang, J. Zhang, J. 2014. Synthesis, Structure, and Characterization of Glyoxal-Urea-Formaldehyde Cocondensed Resins. Journal of Applied polymer Science 131: 1-10.

Dinardo-Miranda, L.L., Fracasso, J.V., Perecin, D. 2011. Variabilidade espacial de populações de Diatraea saccharalis em canaviais e sugestão de métodos de amostragem. Bragantia 70: 577-585.

Dinardo-Miranda, L.L., Anjos, I.A.dos, Costa, V.P.da, Fracasso, J.V. 2012. Resistance of sugarcane cultivars to Diatraea saccharalis. Pesquisa Agropecuária Brasileira 47: 1-7.
Fenech, M., Nersesyan, A., Knasmueller, S. 2016. A systematic review of the association between occupational exposure to formaldehyde and effects on chromosomal DNA damage measured using the cytokinesis-block micronucleus assay in lymphocytes. Mutation Research-Reviews in Mutation Research http://dx.doi.org/10.1016/j. mrrev.2016.04.005

Freitas, M.D.R.T. de, Silva, E.L. da, Mendonça, A.D.L., Silva, C.E. da, Fonseca, A.P.P.da, Mendonça, A.L., Santos, J.S., Nascimento, R.R., Santana, A.E.G. 2007. The biology of Diatraea flavipennella (Lepidoptera: Crambidae) reared under laboratory conditions. Florida Entomologist 90: 309-313.

Huang, F., Leonard, B.R., Gable, R.H. 2006. Comparative susceptibility of european corn borer, southwestern corn borer, and sugarcane borer (Lepidoptera: Crambidae) to Cryl Ab Protein in a commercial Bacillus thuringiensis corn hybrid. Journal of Economic Entomology 99: 194202.

King, E.G., Hartley, G.G. 1985. Diatrea saccharalis. In: Singh, P., Moore, R.F. (Eds.). Handbook of insect rearing. Elsevier, New York, Estados Unidos. 265- $270 \mathrm{pp}$.

Ma, K.M., Chan, C.M., Chung, S.W., Ho, Y.Y., Xiao, Y. 2009. Dietary exposure of secondary school students in Hong Kong to benzoic acid in prepackaged non-alcoholic beverages. Food Additives \& Contaminants: Part A 26: 12-16.

Parra, J.R.P., Botelho, P.S.M., Corrêa-Ferreira, B.S., Bento, J.M.S. 2002. Controle biológico no Brasil Parasitoides e predadores. Malone, São Paulo, Brasil. 609 p.

Portela, G.L.F., Pádua, L.E.M., Branco, R.T.P.C, Barbosa, O.A., Silva, P.R.R. 2010. Flutuação populacional de Diatraea saccharalis (Fabricius, 1794) (Lepidoptera - Crambidae) em canade-açúcar no município de União PI. Revista Brasileira de Ciências Agrárias, 5: 303-307.

Ramalho, D.G, Viel, S.R, Vacari, A.M, De Bortoli S.A, Lopes M.M, Laurentis V.L, Veiga A.C.P. 2012. Criteria for optimization of mass rearing of the parasitoid Cotesia flavipes in the laboratory. Journal of Research in Biology, 2: 529-536.

Reckitt Benckiser. 2010. http://www.rb.com/ documentdownload.axd? documentr esourceid=415<Access April 1st, 2015>.

Santos, R.F., Vacari, A.M., De Bortoli, S.A., De Bortoli, C.P., Santos, J.A. 2015. Development of a New Container for Storage and Release of the Parasitoid Cotesia flavipes (Hymenoptera: Braconidae). Journal of Economic Entomology 108: 969-974. 
Souza, J. R., Boiça Júnior, A.L., Perecin, D., Costa, J.T.C, Peixoto, M.L. 2014. Preferência de Cotesia flavipes (Cameron, 1891) (Hymenoptera: Braconidae) por lagartas de Diatraea saccharalis (Fabricius, 1794) (Lepidoptera: Crambidae) alimentadas com diferentes cultivares de canade-açúcar. Revista Ceres 61: 916-923.

Tayama, K., Iguchi, S., Sasaki, M., Hiraga, K. 1983. Acute oral toxicity of o-phenylphenol (OPP) in mice. Annual Report of Tokyo Metropolitan Research Laboratory of Public Health 34: 325p.

Tang X., BAI, Y., Duong, A., Smith, M.T., Li, L., Zhang, L. 2009. Formaldehyde in China: production, consumption, exposure levels, and health effects. Environent International 35:1210-1224.

Vacari, A.M., Genovez, G.S., Laurentis, V.L., De Bortoli, S.A. (2012a). Fonte proteica na criação de Diatraea saccharalis e seu reflexo na produção e no controle de qualidade de Cotesia flavipes. Bragantia, 71: 355-361.

Vacari, A.M., De Bortoli, S.A., Borba, D.F., Martins, M.I.E.G. 2012b. Quality of Cotesia flavipes (Hymenoptera: Braconidae) reared at different host densities and the estimated cost of its commercial production. Biological Control 63: 102-106.

Weir, E.H., Contreras, L.W., WEIR, K.G. 2007. Biological control of Diatraea spp. (Lepidoptera: Pyralidae) in sugarcane crops in Central Venezuela. Revista de Biologia Tropical 55: 655658. 